УДК 343.14

DOI https://doi.org/10.32689/2522-4603.2021.1.3

\title{
ІГор ЛЕОНЕНКО
}

кандидат юридичних наук, заступник завідувача кафедри правоохоронної та антикорупційної діяльності Навчально-наукового інституту права імені Князя Володимира Великого, Міжрегіональна Академія управління персоналом, вул. Фроментівська, 2, м. Київ, Україна, 03039

\section{Ihor LEONENKO}

Candidate of Law, Deputy Head of the Department of Law Enforcement and Anti-Corruption Activities of the Educational and Scientific Institute of Law named after Prince Vladimir the Great, I nterregional Academy of Personnel Management, 2 Frometivska str., Kyiv, Ukraine, 03039

\section{МІСЦЕ ТА РОЛЬ ПІЗНАННЯ У ДЕТЕКТИВНІЙ (РОЗШУКОВІЙ) ДІЯЛЬНОСТІ}

\section{THE PLACE AND ROLE OF COGNITION IN DETECTIVE (INVESTIGATIVE) ACTIVITIES}

\begin{abstract}
У статті розглянуто місие та роль пізнання у детективній (розшуковій) діяльності. Проведено аналіз та порівняння прочесуальних категорій «пошук» та «розшук» між собою. Визначено послідовність провадження вказаних пізнавальних процесів у детективній (розшуковій) діяльності.
\end{abstract}

Ключові слова: пізнання, пошук, розшук, детектив, діяльність, об'єкт, суб'єкт, свідомість, прочесс.

The article considers the place and role of cognition in detective (investigative) activities. The analysis and comparison of procedural categories "search" and "search" with each other is carried out. The sequence of carrying out of the specified cognitive processes in detective (search) activity is defined.

Key words: cognition, search, search, detective, activity, object, subject, consciousness, process.

Актуальність проблеми. У своїй професійній діяльності слідчий або детектив так чи інакше вимушений максимально задіювати свої розумові здібності. Адже основним завданням детектива являється викриття осіб, причетних до скоєння кримінального правопорушення, встановлення їх місцезнаходження та притягнення до кримінальної відповідальності.

Сьогодні ми живемо у світі новітніх технологій. Завдяки різноманітним гаджетам та електронним винаходам людина все менше застосовує свої мисленеві процеси. Однак жодний штучний інтелект (пристрій) не здатен замінити розум людини. Лише завдяки пізнавальним процесам, логічним прийомам, а в деяких випадках навіть інтуїції, детектив здатний прийняти вірне рішення, встановити істину у тій чи іншій справі.

Аналіз останніх досліджень і публікацій. У вітчизняній юридичній науці явище пізнання як елемент детективої (розшукової) діяльності окремо не досліджувалось. Натомість існує багато наукових праць, присвячених проблематиці доказування у кримінальному процесі та оперативно-розшуковій діяльності, крізь які стрижнем проходить феномен пізнання. Вагомий внесок у розв'язання вказаної проблематики зробили такі видатні вчені-процесуалісти, як Удалова Л. Д., Сервецький І. В., Кислий А. М., Грошевой Ю. М., Стахівський С. М., Рожнова В. В., Саковський А. А., Никифорчук Д. Й. та ін.

Метою даної статті визначення місця та ролі пізнання у детективній (розшуковій) діяльності під час провадження досудового розслідування.

Виклад основного матеріалу. Об 'єкm пізнання у сфері детективної (розшукової) діяль$н о с т і$ - це реальні явища, події, процеси, речі, які є предметом цілеспрямованої пізнавальної активності детектива.

Пізнавальна діяльність неможлива без наявності суб 'єкта пізнання - людини або тієї чи іншої спільноти, коли вони не просто відображають реальну дійсність, а утворюють нові знання, нові цінності, нові світоглядні парадигми суспільства [7, с. 43].

Слід зазначити, що пізнавальна діяльність у сфері детективної (розшукової) діяльності має специфічний суб'єкт пізнання - детектива.

Таким чином, суб'єкт і об'єкт пізнання перебувають у постійному взаємозв'язку між собою. Пізнання реальності не може відбутися, якщо немає кому пізнавати і немає що 
пізнавати. Активність виходить від суб'єкта пізнання, взаємодіє з ним з допомогою відповідних засобів задля пізнання його сутності, досягнення істини [8, с. 143].

Засоби пізнання у сфері детективної (розшукової) діяльності являють собою зумовлену багаторічним досвідом, відносно стійку систему гласних і негласних заходів та науково-технічних засобів, що використовуються в процесі здобуття необхідної інформації (відомостей).

Мета пізнання це цікавість та допитливість, бажання встановити істину - ці риси притаманні будь-якій дієздатній особі. Одвічні питання: «Що?», «Де?», «Коли?», так чи інакше супроводжують всю історію розвитку людства.

Процес здобуття певних знань з метою встановлення істини за допомогою розумової діяльності отримав назву пізнання. Якщо розглядати детективну діяльність, як комплекс розшукових заходів, то саме пізнання являється базисом розшукових дій.

Так, у Академічному тлумачному словнику української мови пізнання розуміється як відображення в свідомості людини явищ реальної дійсності, їх суті [1].

Більш вузьке визначення терміну «пізнання» надає Філософський словник, за яким пізнання - це зумовлений законами соціального розвитку, нерозривно пов'язаний 3 практикою процес активно-діяльного відображення в свідомості людей об'єктивної та суб'єктивної дійсності, основним результатом якої є знання [2].

Здобуваючиінформацію(знання)про явища об'єктивної дійсності, людина поступово розвивається. Пізнання - рушійна сила всіх революційних перетворень в науці й техніці.

Однак само по собі «пізнання» не являється вихідною точкою. Цьому розумовому процесу, як вважають деякі науковці, передує чуттєве сприйняття, яке полягає у накопичуванні фактів (інформації) та являється першим етапом на шляху до пізнання [3, с. 10].

Маючи певний досвід та знання, людина починає логічно обробляти та аналізувати відомості, якими вона володіє, спираючись на безпосередній досвід. Іншими словами, людина починає раціонально мислити. Адже розуміння об'єкта можливо лише шляхом логічного мислення 3 використанням таких розумових операцій як порівняння, абстракція i конкретизація, індукція i дедукція i, нарешті, заключний синтез [4, с. 234].

Отже, пізнання - це сукупність процесів, завдяки яким людина отримує, переробляє і використовує інформацію про світ і про саму себе [5, с. 61]. В свою чергу, процес пізнання певної події чи явища становить єдність безпосереднього, почуттєвого, опосередкованого й раціонального способів здобуття знання.

Пізнання здійснюється, в свою чергу, за допомогоюпізнавальноїдіяльності, тобтовиду людської діяльності, який тісно пов'язаний 3 іншими формами діяльності і спрямований на отримання, обгрунтування, розширення та оновлення існуючого знання [6, с. 193].

В літературі справедливо зазначається, що конкретні речі, явища, процеси, на які безпосередньо спрямована пізнавальна діяльність людей, прийнято називати об'єктом пізнання [5, с. 61]. Пізнаючи той чи інший об'єкт людина починає з його зовнішнього опису, фіксує окремі його ознаки, риси, властивості.

Невід'ємною складовою пізнання та пізнавальної діяльності являється пошук.

ВАкадемічномутлумачномусловникуукраїнської мови слово «пошук» має декілька значень: 1) шукання, розшукування чого-небудь; 2) творча робота, спрямована на відкриття нового в науці, мистецтві, на виробництві i т. ін. та 3) розвідка із захопленням документів, зразків зброї, язика (полоненого) і т. ін. [1].

Вікіпедія тлумачить слово «пошук» як прагнення домогтися чого-небудь, щось знайти або дії, спрямовані на отримання нового або загубленого [9].

Як бачимо, спільним у визначенні пошуку $\epsilon$ два значення - 1) шукання, розшукування та 2) діï, спрямовані на відкриття чогось нового.

У першому значенні (ретроспективному) дії направлені в минуле, тобто спрямовані на розшук чогось втраченого або когось зниклого (інформації, особи, речі тощо). У другому випадку (перспективному) дії направлені в майбутнє, тобто спрямовані на пошук чогось нового, невідомого донині (наприклад, науковий винахід або явище в природі).

\section{Висновки i перспективи подальших} досліджень. Отже, категорії «пізнання» та «пошук» мають багато спільного. Різниця полягає лише в тому, на що саме спрямовані ці категорії. Так, якщо пошук направлений на встановлення місцезнаходження якогось конкретного об'єкта (наприклад, пошук істини), то пізнання - це нескінченний процес, який триває протягом усього життя людини та має на меті отримання та аналіз інформації про всі невідомі людині явища об'єктивної дійсності.

Таким чином, пошук (розшук) має конкретну мету, після досягнення якої він припиняється. Натомість, пізнання не має конкретно визначеної мети, воно всеохоплююче та припиняється лише зі смертю людини. Саме тому пізнання завжди буде первинним явищем по відношенню до всіх інших розумових та розшукових процесів. 


\section{Література:}

1. Академічний тлумачний словник української мови (1970-1980). URL: sum.in.ua

2. Філософський словник. URL: naiau.kiev.ua

3. Оперативно-розшукова діяльність: навч. посіб. / Є. М. Моісеєв, О. М. Джужа, Д. Й. Никифорчук та ін. / за ред. проф. О. М. Джужи. Київ : Правова єдність, 2009. 310 с.

4. Меленевська 3. С., Сизоненко А. С. Питання психології експертного дослідження почерку та формування висновків. Судово-експертна діяльність: сучасний стан та перспективи розвитку : збірник матеріалів круглого столу. Київ : ННІПФЕКП НАВС, 2015. 444 с.

5. Вступ до філософії : навч.-метод. посібник / за ред.. Л. М. Нікітіна. Київ : ЦУЛ, 2008. 256 с.

6. Общие проблемы философии науки: Словарь для аспирантов и соискателей / под общ. ред. Н.В. Бряник. Екатеринбург : Изд-во Урал. ун-та, 2007. 318 с.

7. Біленчук П.Д. Засоби пізнання у сфері кримінального судочинства: наукові засади систематизації та особливості використання. Книга 1. Загальнотеоретична характеристика засобів пізнання у сфері кримінального судочинства: проблеми методології, системології, праксеології : Монографія. Хмельницький : ХмЦНІІ, 2012. 372 с.

8. Губерський Л.В., Кремень В.Г., Приятельчук А.О. та ін. Людина і світ : Підручник. Київ : Т-во «Знання», KОО, 2001. 350 c.

9. Вікіпедія. URL: https://uk.wikipedia.org/wiki/

\section{References:}

1. Akademichnyi tlumachnyi slovnyk ukrainskoi movy (1970-1980) [Academic Interpretive Dictionary of the Ukrainian Language (1970-1980)]. URL: sum.in.ua

2. Filosofskyi slovnyk [Philosophical dictionary]. URL: naiau.kiev.ua

3. Moiseiev, Ye. M., Dzhuzha, O. M., Nykyforchuk, D. Y. ta in. (2009) Operatyvno-rozshukova diialnist: navch. posib. [Operational and investigative activities: textbook]. Kyiv : Pravova yednist [in Ukrainian].

4. Melenevska, Z. S., Syzonenko, A. S. (2015) Pytannia psykholohii ekspertnoho doslidzhennia pocherku ta formuvannia vysnovkiv [Questions of psychology of expert research of handwriting and formation of conclusions]. Sudovo-ekspertna diialnist: suchasnyi stan ta perspektyvy rozvytku : zbirnyk materialiv kruhloho stolu. Kyiv : NNIPFEKP NAVS [in Ukrainian].

5. Nikitina, L. M. (ed.) (2008) Vstup do filosofii : navch.-metod. posibnyk [Introduction to philosophy: teaching method. manual]. Kyiv : TsUL [in Ukrainian].

6. Bryanik, N.V. (ed.) (2007) Obshie problemy filosofii nauki: Slovar dlya aspirantov i soiskatelej [General problems of philosophy of science: Dictionary for graduate students and applicants]. Ekaterinburg : Izd-vo Ural. un-ta [in Russian].

7. Bilenchuk, P.D. (2012) Zasoby piznannia u sferi kryminalnoho sudochynstva: naukovi zasady systematyzatsii ta osoblyvosti vykorystannia. Knyha 1 . Zahalnoteoretychna kharakterystyka zasobiv piznannia u sferi kryminalnoho sudochynstva: problemy metodolohii, systemolohii, prakseolohii : Monohrafiia [Means of knowledge in the field of criminal justice: scientific principles of systematization and features of use. Book 1. General theoretical characteristics of the means of knowledge in the field of criminal justice: problems of methodology, systemology, praxeology: Monograph]. Khmelnytskyi : KhmTsNII [in Ukrainian].

8. Huberskyi, L.V., Kremen, V.H., Pryiatelchuk, A.O. ta in. (2001) Liudyna i svit : Pidruchnyk [Man and the World: a textbook]. Kyiv : T-vo «Znannia», KOO [in Ukrainian].

9. Vikipediia [Wikipedia]. URL: https://uk.wikipedia.org/wiki/ 